\title{
The Journal of
}

\section{Laryngology and Otology}

\author{
EDITED BY \\ WALTER HOWARTH \\ WHTH THE ASSISTANCE OF \\ W. M. MOLIISON
}

\section{Contents}

Oto-Rhinotogical. Probtemss of Otrensivie Divina

FRAESTRATION OF THE LABYRINTH

CLINTCAL RECORD-

FrBRo-ANGTOMa of the Rrght ALA NASt iN $\Lambda$ BOY OH TWO YRARS : ? ?

SOCIETHES' ProckBDINGS-

Roval. SOCHETY of MEDICINE-SEction of LARYRGOLOGY

Revinw of Book
S. GAY-FRENCH

O. POPPER

\section{London}

\section{Headley Brothers}

tog Kingsway, W.C.2 


\title{
The Journal of
}

\section{Laryngology and Otology}

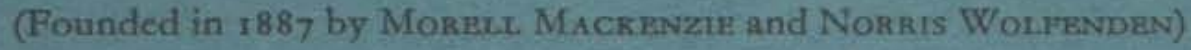

\author{
EDITED BY \\ WALTER HOWARTH \\ ASSISTRE BY \\ W. M. MOLIISON
}

1. Original Atticles are accepted on the condition that they have not been published elsewhere.

2. Manuscripts should be typewritten, on one side only of the paper, and well spaced.

3. Galley proofs and engraver's proofs of illustrations are sent to the suthor. Corrections, which should be kept to a minimum, must be clearly marked and no additional matter added.

4. Orders for reprints should be sent when returning galley proofs, and for this purpose special forms are supplied, on which the price of the reprints is stated.

5. Authors of Original Communications on Oto-Laryngology in other Journals are invited to send a copy, or two reprints, to the Journal of Laryngology. If they are willing, at the same time, to submit their own abstract (in English, French, Italian, or German) it will be welcomed.

6. Editorial Communications may be addressed to THA Firor, Jowrnal of Laryngology, c/o HradiBy Brothens, tog Kingsway, London, W.C.z.

7. The Annual Subscription commencing with the January issue is Two Pounds sterling, post free, and is payable in advance.

8. Single copies, both of the present and the previous series, are on sale at Four Shillings each.

9. All Subscriptions, advertising and business communications should be sent to the Publishers, Headuex Brotrinas, rog Kingsway, London, W.C.z.

\section{United Shates of America}

Orders for this Joumal may be sent either through a local bookseller, or to Messrs. G. E. Strchert \& Co.2 31-33 East roth Street, New York, or may be sent direct to the Publishers, HBapley Brothers, rog Kingsway, London, W.C.2, England. 
SHORTENS THE COURSE OF INFECTION AND AVERTS SEQUELÆ TO COLDS

(6)

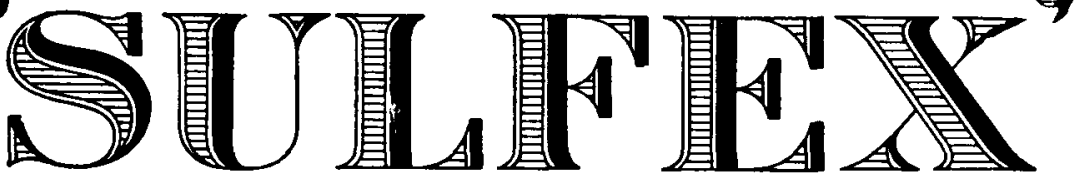

(A suspension of micro-crystalline ('Mickraform') sulphathiazole, $5 \%$, in an isotonic solution of 'Paredrinex,' $1 \%$ ).

'Sulfex'* has proved strikingly effective, both with adults and children, in the treatment of nasal and sinus infectionsespecially those secondary to common colds. Nasopharyngeal sore throat often responds to 'Sulfex' within twenty-four hours. The suspension has the following advantages :-

(1) PROLONGED BACTERIOSTASIS. The 'Mickraform '* crystals of free sulphathiazole are not quickly washed away, but form an even frosting over the nasal mucosa, thus providing prolonged bacteriostasis precisely where it is needed most.

(2) NON-STIMULATING VASOCONSTRICTION. While 'Paredrinex '* exerts a rapid and complete shrinking action, it does not produce nervous side-effects such as restlessness and insomnia.

(3) THERAPEUTICALLY IDEAL $\mathrm{pH}(5 \cdot 5$ to $6 \cdot 5)$. 'Sulfex' does not cause stinging or irritation. Its slightly acid $\mathrm{pH}$ range is identical with that of normal nasal secretions.

Available, on prescription only, in 1-oz. bottles with dropper. Price 5/1 including P.T. Special 8-oz. pack for hospitals.

Samples and further details on signed request of physicians.

\section{MENLEY \& JAMES LIMITED}

123, COLDHARBOUR LANE, LONDON, S.E. 5

For Smith, Kline \& French Laboratories, owners of the Trade Marks*

Please mention The Journal of Laryngology when replying to advertisements 

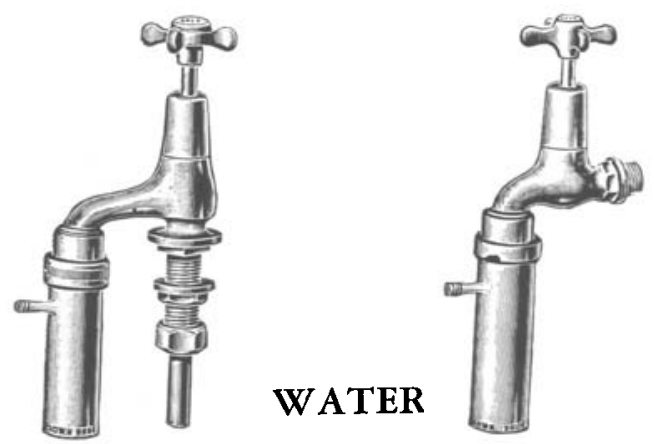

\section{SUCTION APPARATUS}

Particulars on application

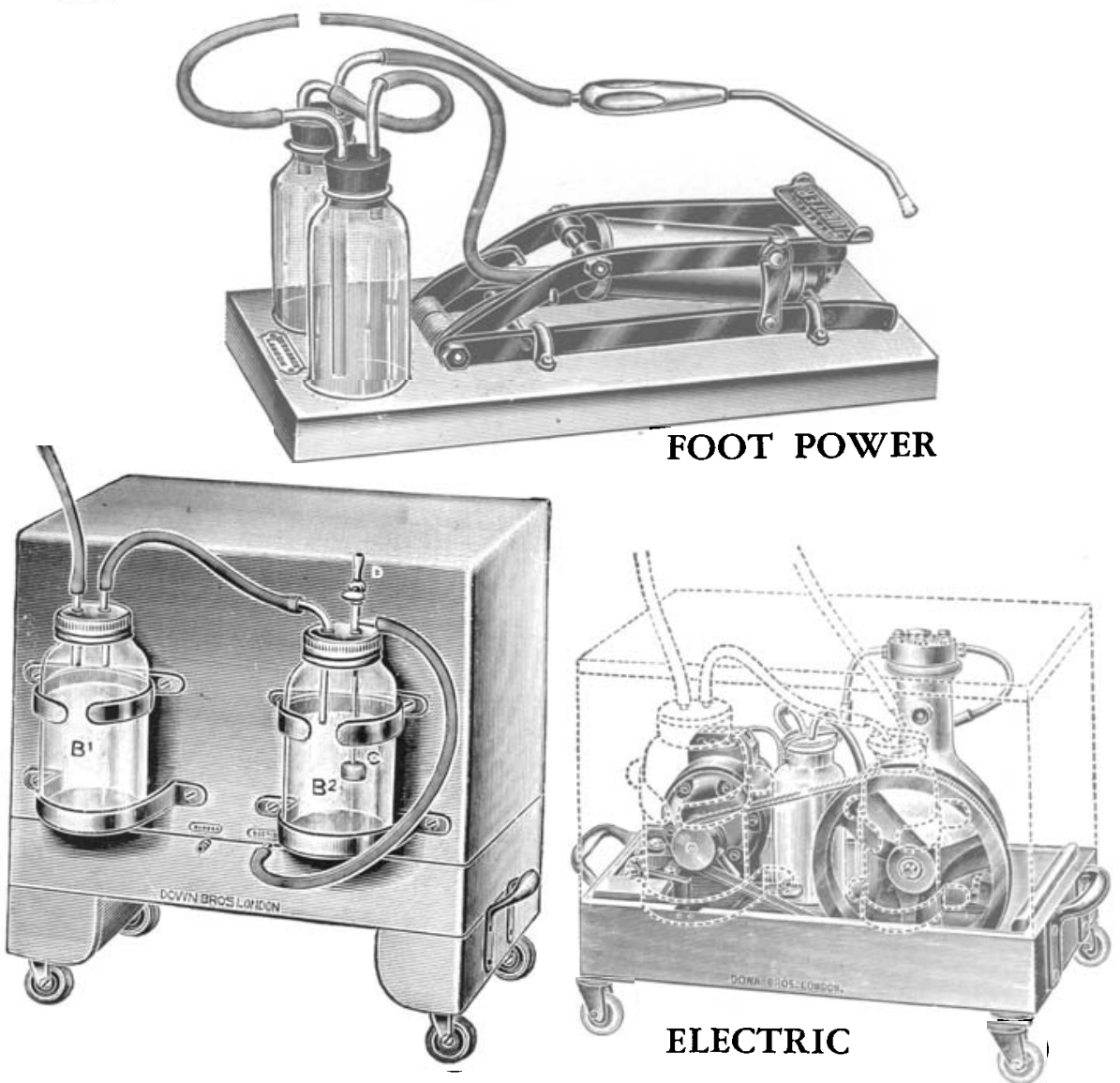

\section{DOWN BROS. \& MAYER \& PHELPS Ltd.}

Correspondence: 23 PARK HILL RISE, CROYDON

Telephone: Croydon 6133,6134, 6r35

Showrooms: 22a CAVENDISH SQUARE, LONDON, W.I

Telephone: MAYFAIR 0406

IN ORDER TO COPE MORE EFFECTIVELY WITH THE DIFFICULTIES OF THE POST-WAR SITUATION IN THE PRODUCTION OF THE HIGHEST CLASS OF SURGICAL INSTR MFNTS AND ASEPTIC HOSPITAL, FURNITURE, DOWN BROS. AND MAYER \& PHELPS HAYE AMALGAMATED. THE PERSOYAL MANAGEMENTS REMAIN AS HERE'TOFORE.

Please mention The Journal of Laryngology when replying to advertisements 


\section{PRESCRIBE THE EASY EFFECTIVE METHOD}

When spraying, the patient can hold his head in a natural position, yet the solution spreads throughout the nasal cavity, assuring thorough treatment. Effective dropper-application, on the other hand, requires a complicated posture technique which patients are apt to neglect in home treatment.
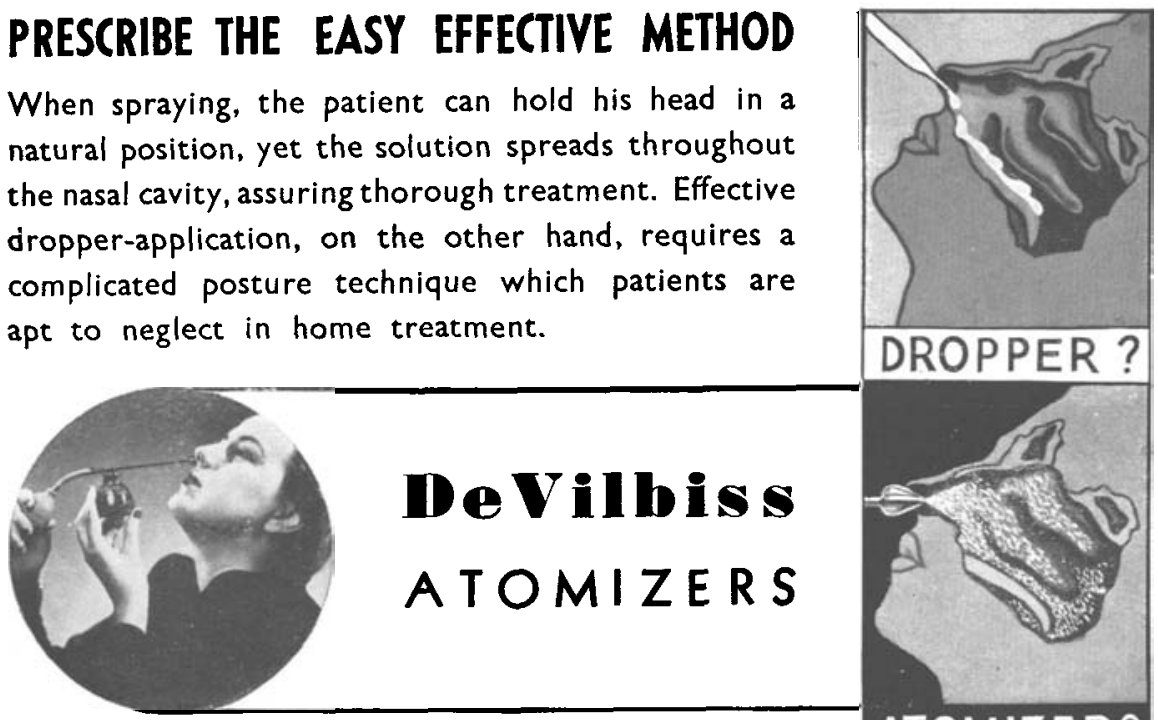

These illustrations, which are based on X-ray research, clearly demonstrate

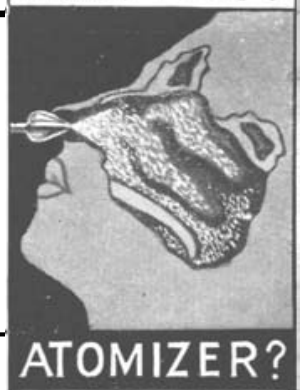
the advantazes of the atomizer as compared with the dropper

The AEROGRAPH Co., Ltd., Lower Sydenham, London, S.E.26 Sole Distributors of DeVilbiss Products in the United Kingdom. Telephones: Sydenham 6060-8 Lines.

cvs-225

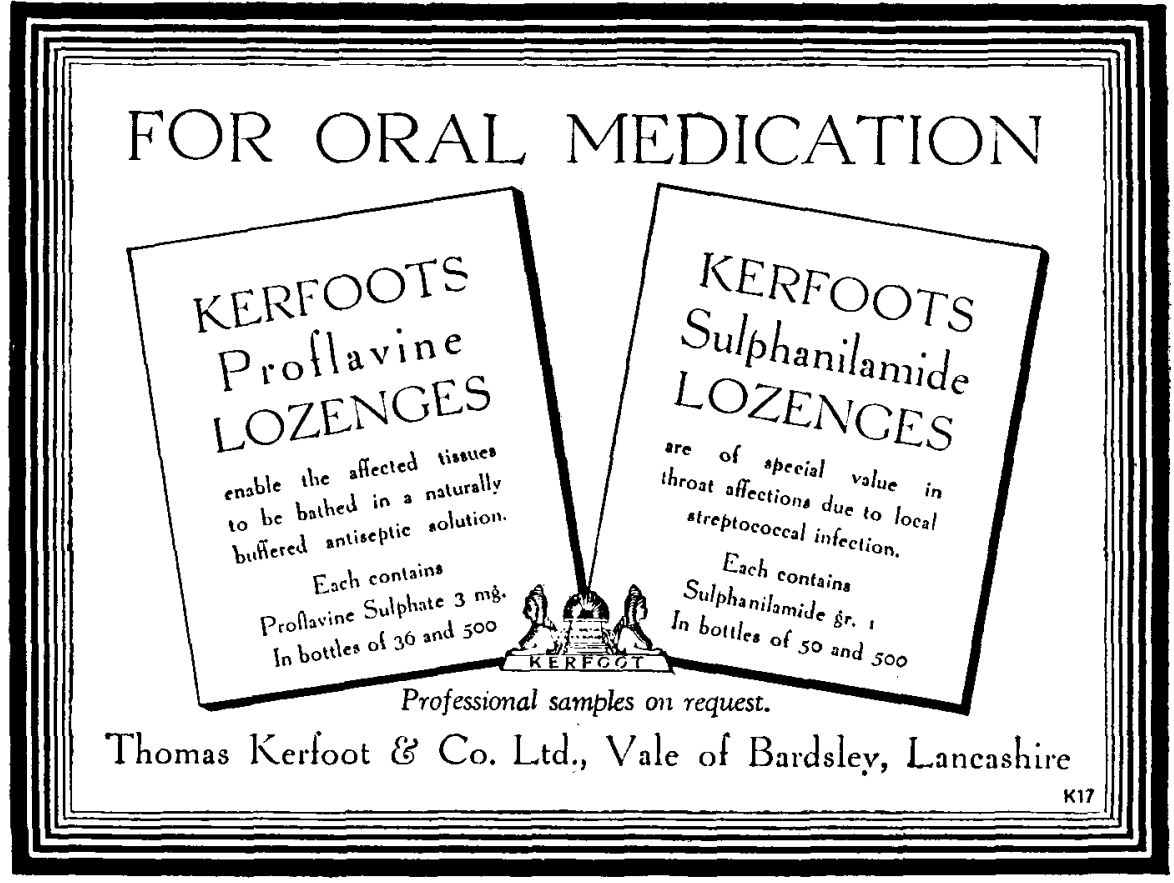

Please mention The Journal of Laryngology when replying to advertisements 


\section{CONTENTS}

Oro-Rhinological Problems of Offensive Diving. Surgeon Commander S. Gay-French, R.N.(Retd.) . . . $4^{\mathrm{I}} 7$

Fenestration of the Labyrinth. O. Popper (Johannesburg) $4^{\mathrm{I}}$

Clinical Record-

Fibro-Angioma of the Right Ala Nasi in a Boy of Two Years.

C. de W. Gibb (Gloucester)

Societies' Proceedings-

Royal Society of Medicine-Section of Laryngology . . $\quad f^{60}$

REVIEW OF BoOK . . . . . . . . . . . 4 4 I

\section{Mail Your Order Now! \\ PROBLEMS OF THE DEAF}

By MAX A. GOLDSTEIN, M.D., F.A.C.S.

6ro Pages-273 Illustrations-Leather Bound

\$6.00 Postage prepaid

An unusual, authoritative and comprehensive volume of XIX chapters, covering every phase of work with the Deaf, Deafened and Speech Defective, by an otologist and teacher of $4 \circ$ years' experience, including :

Chronological History of Deafness-Anatomy and Physiology-Mechanics of Speech-Speech Defects-Cerebral Localization-Hearing 'Tests-Methods of Instruction-The Acoustic Method-Training of Teachers-The Deaf Child-Hardof-Hearing Child-Physician and Deaf Child-Parent of Deaf Child-Deafened Adult-Hearing Aids-Schools for the Deaf-Quacks and Quackeries-Research.

\section{Published by THE LARYNGOSCOPE PRESS}

640 South Kingshighway ST. LOUIS, MO.

\section{UNIVERSITY OF LONDON}

Applications are invited for the Geoffrey E. Duveen Studentship for 1948, value $f_{550}$, for research in any aspect of Oto-Rhino-Laryngology. Further particulars and forms of application (to be received by Nov. 3oth, 1947) may be obtained from the Academic Registrar, Senate House, University of London, W.C.I

Please mention The Journal of Laryngology' when replying to advertisements 